\title{
Assessing the Sumatran tiger Panthera tigris sumatrae population in Batang Gadis National Park, a new protected area in Indonesia
}

\author{
Hariyo T. Wibisono, Joe J. Figel, Sugesti M. Arif \\ Anton Ario and A bu H. Lubis
}

\begin{abstract}
The $1,080 \mathrm{~km}^{2}$ Batang Gadis National Park in the North Sumatra province of Indonesia was established in December 2004 by the regional government of Mandailing Natal district. The Park has the potential to make an important contribution to tiger conservation but lacks scientific data on the occurrence of the species. This study aimed to assess the tiger population of the Park, using camera trapping conducted between December 2005 and July 2006. We recorded a mean tiger density of 1.8 tigers per $100 \mathrm{~km}^{2}$ (95\% CI 1.8-6.4) and, based on this, estimated the tiger population in and adjacent to the Park to be 29103 adults. We found that tiger presence was negatively correlated with altitude and positively correlated with distance from forest edge to the interior, and $<18 \%$ of the total suitable habitat occupied by tigers was of high quality. This study indicates that Batang Gadis National Park potentially serves as a natural corridor betwen the Angkola and Barumun-Rokan ecosystems, areas totalling c. $6,500 \mathrm{~km}^{2}$, and that this landscape could serve as a stronghold for tiger populations in northern Sumatra.
\end{abstract}

Keywords Camera trapping, capture-recapture, conservation, Indonesia, Panthera tigris, Sumatra

\section{Introduction}

Tiger Panthera tigris populations continue to decline 1 throughout their range (Dinerstein et al., 2006). This decline is because of the illegal trade in their body parts for traditional medicine, authorized removal of problem tigers following tiger-human conflicts (Tilson et al., 1994; Seidensticker et al., 1999), depletion of prey species (Seidensticker, 1986; Karanth \& Stith, 1999), and accelerated destruction of their natural habitat (Dinerstein et al., 2006).

Indonesia historically contained three subspecies of tigers but both the Javan subspecies $P$. t. sondaica and the

Hariyo T. Wibisono Wildlife Conservation Society Indonesia Program, Bogor, West Java, Indonesia.

Joe J. Figel (Corresponding author) Environmental Studies Department, Florida International University, Miami, FL 33199, USA. E-mail jfige001@fiu.edu

Sugesti M. Arif, Anton Ario and Abu H. Lubis Conservation International Indonesia, Kemang, Jakarta, Indonesia.

Received 2 April 2008. Revision requested 16 July 2008.

Accepted 27 October 2008.
Bali subspecies $P$. t. balica went extinct in the early $1980 \mathrm{~s}$ and 1940s, respectively (Seidensticker, 1986; Seidensticker et al., 1999). Currently, only the Sumatran subspecies P. t. sumatrae persists, in isolated populations throughout Sumatra (Dinerstein et al., 2006). In 1978 the Sumatran tiger population was estimated to be 1,00o (Borner, 1978). In 1985 26 protected areas were found to contain a total of 800 tigers (Santiapillai \& Ramono, 1987). In 1992, a Population and Habitat Viability Analysis estimated there were only 400500 Sumatran tigers in the wild (Tilson et al., 1994). The aims of the present study were to make the first estimate of the density of tigers in the recently gazetted Batang Gadis National Park and to identify the environmental variables that best predict tiger occurrence in the Park.

\section{Study area}

Batang Gadis National Park in North Sumatra Province, Indonesia, is one of 12 forest blocks in Sumatra, including national parks, identified as a level 3 Tiger Conservation Landscape. Sanderson et al. (2006) defined level 3 Tiger Conservation Landscapes as those that have habitat to support some tigers but that have moderate to high levels of threat and minimal conservation investment. Under a new legal framework that allows local governments to declare national parks, the governor of North Sumatra and the head of Mandailing Natal district declared $26 \%$ of the total forested area in the district as Batang Gadis National Park in December 2004. Covering a total of $1,080 \mathrm{~km}^{2}$ of tropical rainforest, the Park has an altitude range of $300-2,145 \mathrm{~m}$ (Sorik Merapi mountain; Fig. 1). Rainfall is seasonal, with an annual range of 1,900-2,800 $\mathrm{mm}$ over 2002-2006 (BMG, 2008).

\section{Methods}

Large mammal surveys were conducted in eight periods between December 2005 and July 2006. Twenty-six passive infrared camera traps (Deercam, Park Falls, USA) were used, each with data packs that record time and date on the photographs. Cameras were placed in a $16 \times 16 \mathrm{~km}^{2}$ sampling block in the centre of the Park (Fig. 1). The sampling block was divided into 16 equal-sized cells, with two cameras in each cell. Camera sites were chosen based on areas that had tiger or prey signs. Cameras were active 


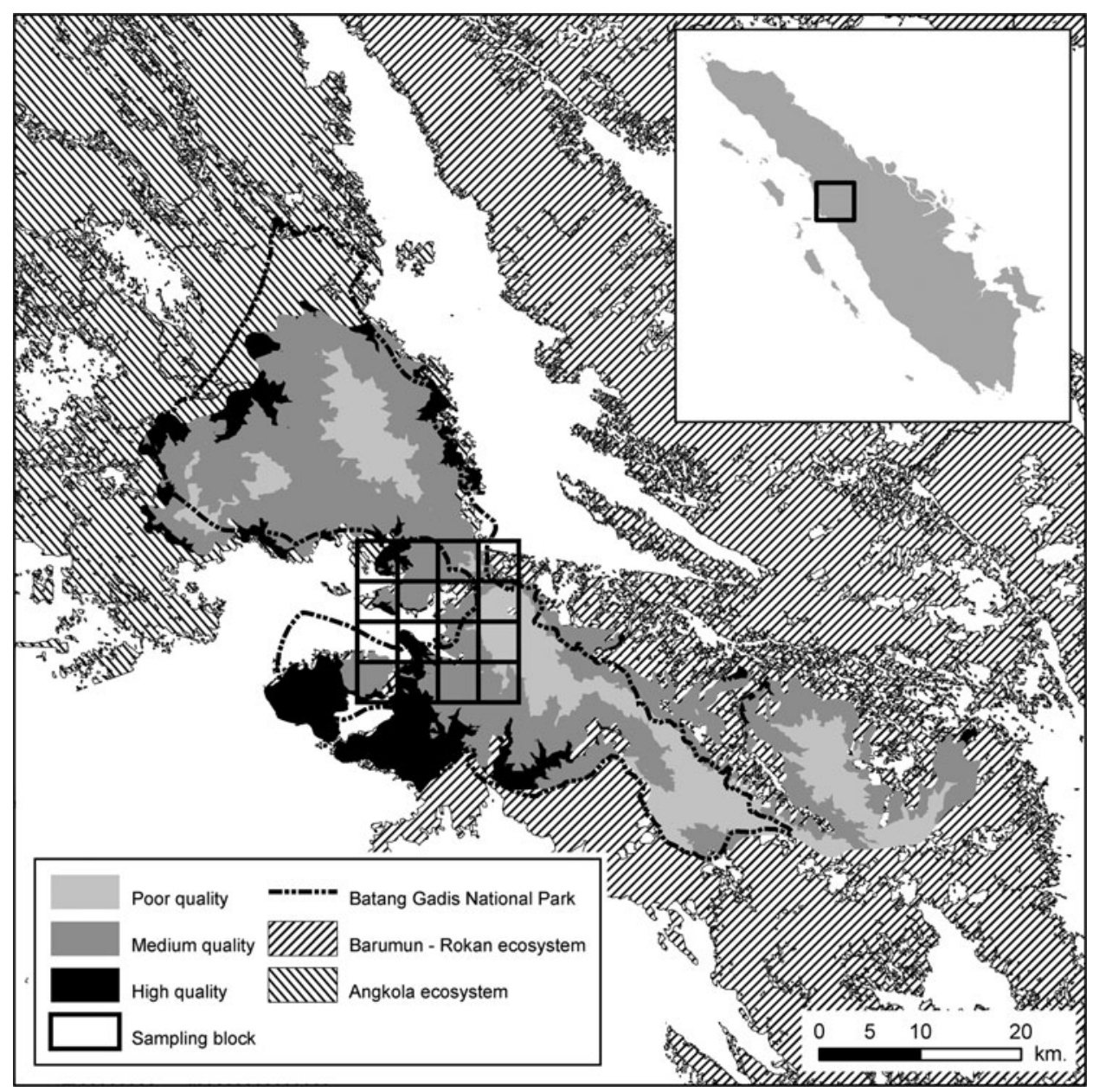

FIG. 1 Batang Gadis National Park, Mandailing Natal District, North Sumatra, with the sampling block of $256 \mathrm{~km}^{2}(16 \times 16 \mathrm{~km}$ divided into $4 \times 4 \mathrm{~km}$ cells) where camera-trapping took place (see text for further details), and poor, medium and high quality tiger habitat as determined by a model of tiger presence (see Table 1 and text for further details). The rectangle on the inset indicates the location of the main map in Sumatra.

24 hours per day and operated for 20-30 days in each period. The number of trap days for each film was defined as from the activation of the camera until the film was retrieved, if the film had exposures remaining, or until the time and date stamp on the final exposure. Each animal photo was identified to species. We used the number of photographs of each species to construct a respective relative abundance index (O'Brien et al., 2003). We deployed the cameras at 32 different locations with a mean altitude of $983 \pm$ SD $253 \mathrm{~m}$. The average distance between cameras was 2,062 $\mathrm{m}$ (range 286-4,391 m). This prevented holes in the sampled area where the probability of capturing tigers was zero (Karanth et al., 2002).

Linkie et al. (2006) suggested the following environmental variables as potential predictors for tiger occurrence: mean distance to public and logging roads, settlements and rivers, and altitude, slope and protected status. In addition, O'Brien et al. (2003) and Linkie et al. (2008) found a negative correlation between tiger occurrence and distance to forest edges. To test the relationship between tiger abundance and environmental variables a geographical information system (GIS) data set containing seven variables was constructed with ArcGIS v. 9.1 (ESRI, Redlands, USA): slope (degree); distance to rivers (50 $\mathrm{m}$ intervals); river length $(\mathrm{km})$; distance from forest edge to its interior (50 $\mathrm{m}$ intervals); distance to district roads $(\mathrm{km})$; distance to villages $(\mathrm{km})$; and altitude (50 m intervals; Table 1). Altitude and slope data were obtained from Digital Elevation Map SRTM o7 (USGS, 2004) and data for the remaining variables from the National Coordinating Agency for Surveys and Mapping (BAKOSURTANAL) in 2005.

We used the software CAPTURE (Patuxent Wildlife Research Center, Laurel, USA; Rexstad \& Burnham, 1991) to estimate tiger capture probabilities and then abundance as recommended by Karanth \& Nichols (2002). In capturerecapture models abundance estimation requires that the population be closed i.e. no births, deaths, immigration or emigration during the sampling period (Otis et al., 1978). The closure assumption was examined using the closure test in CAPTURE (Otis et al., 1978). For each individual 
TABLE 1 The best multiple logistic regression model, obtained using stepwise selection procedures, for predicting tiger presence. A total of seven environmental variables were evaluated for inclusion (see text for further details).

\begin{tabular}{|c|c|c|c|c|c|c|c|c|}
\hline \multicolumn{6}{|c|}{ Analysis of Maximum Likelihood Estimates } & \multicolumn{3}{|c|}{ Odd ratio estimates } \\
\hline \multirow[b]{2}{*}{ Parameter } & \multirow[b]{2}{*}{ df } & \multirow[b]{2}{*}{ Estimate } & \multirow[b]{2}{*}{ SE } & \multirow[b]{2}{*}{ Wald $\chi^{2}$} & \multirow[b]{2}{*}{$\mathrm{P}$} & \multirow[b]{2}{*}{ Estimate } & \multicolumn{2}{|c|}{ 95\% Wald's confidence limit } \\
\hline & & & & & & & Min. & Max. \\
\hline Intercept & 1 & 1.143 & 2.508 & 0.208 & 0.648 & & & \\
\hline Distance to forest edge & 1 & 1.731 & 0.854 & 4.111 & 0.043 & 5.646 & 1.059 & 30.093 \\
\hline Altitude & 1 & -5.537 & 2.362 & 5.497 & 0.019 & 0.004 & $<0.001$ & 0.403 \\
\hline
\end{tabular}

tiger, identified from its stripe pattern, we constructed unique capture histories (O’Brien et al., 2003). All analyses were confined to photographs of the right flank because this side had the largest number of identified and recaptured individuals. Each trapping day was treated as one sampling occasion, giving an average of 20 sampling occasions for the analysis. We used model $\mathrm{Mh}$, which allows for a variable capture probability between individuals and is more reliable and robust to the violation of assumptions (Otis et al., 1978). To calculate tiger density the estimated tiger abundance from model $\mathrm{Mh}$ was divided by the effective sampling area, defined as the outermost camera locations, plus an added buffer zone with equal width to the mean maximum distance moved (MMDM) of recaptured tigers (Nichols \& Karanth, 2002).

We used logistic regression to evaluate the probability of tiger presence based on the seven environmental variables (log transformed). Tiger occurrence was the binary response variable and the environmental factors the explanatory variables. We based our decisions on stepwise selection procedures. The fit of the data with the model was assessed using deviance and Pearson goodness-of-fit statistics. Potential collinearity of explanatory variables was assessed using a nonparametric Spearman correlation analysis. We used $r_{s} \pm 0.33$ as a cut off for strong collinearity between variables for $\mathrm{n}=60$ and $\mathrm{P}=0.01$ (Gibbons, 1978). If two variables were highly correlated the one with the lower Wald $\chi^{2}$ in the full model was removed. Wald $\chi^{2}$ is the squared ratio between the point estimate and associated standard error. Thus we removed the variables with the lower Wald $\chi^{2}$ because they were weaker in predicting tiger occurrence.

A predictive model of tiger distribution was generated using distance from forest boundaries and elevation, the two environmental variables that best predicted tiger presence. A GIS analysis was used to create a predictive model of tiger habitat quality. Using the reclassify tool the altitude and distance from forest boundary layers were reclassified into 10 equal intervals and ranked between 1 and 10 with respect to the effect of each variable in predicting tiger occurrence. The two new layers were then combined using the map algebra tool of ArcGIS Spatial Analyst. The resulting layer was ranked into three categories of tiger habitat: poor, medium and high quality. The extent of this predictive map was based on forest boundaries.

\section{Results}

A total of 102 films were exposed at the 32 locations. We obtained a total of 364 animal photos, including tigers, representing at least 24 species in a total of 1,728 trap-days. A total of 10 tiger photographs of the right flank, including duplicates and unidentified individuals, were obtained. The quality of one photograph was too poor for identification. The number of unique individuals identified was six. Using CAPTURE model $\mathrm{Mh}$ we estimated an average capture probability of 0.08 . The estimated tiger population size in the sampled area was $6 \pm$ SE 2.4, with a $95 \%$ confidence interval (CI) of 6-21. The coefficient of variation $(\mathrm{CV})$ was 40.0, indicating a lack of precision. The small sample size of only six unique tigers and three recaptures precluded more accurate estimates. Small sample sizes are common in tiger studies (Karanth \& Nichols, 2000; Lynam et al., 2008).

A closure test indicated that our population did not differ significantly from a closed population $(z=0.126$, $\mathrm{P}=0.55$ ). The MMDM between recaptured tiger individuals was $4.5 \mathrm{~km}$, leading to an estimated total sampling coverage of $431 \mathrm{~km}^{2}$. We calculated the habitat actually sampled by subtracting the amount of non-forested areas from this total coverage, which gave an area of $327 \mathrm{~km}^{2}$. Using the estimated tiger population size in the sampled area with the effective sampling coverage of suitable habitat, we estimated the density of tigers to be 1.8 per $100 \mathrm{~km}^{2}$ (95\% $\mathrm{CI}=1.8-6.4)$. Assuming this estimate reflects tiger densities in suitable habitat in and adjacent to the Park of c. 1,607 km², we estimated that 29-103 tigers live in this area.

We found significant collinearity between distance from rivers and river length $\left(r_{s}=-0.62, \mathrm{P}<0.001\right)$, distance from forest edges and villages $\left(r_{s}=0.749, \mathrm{P}<0.001\right)$, distance from roads and villages $\left(r_{s}=0.797, \mathrm{P}<0.001\right)$, distance from roads and distance from forest $\left(r_{s}=0.650, \mathrm{P}<0.001\right)$, altitude and distance from rivers $\left(r_{s}=0.357, \mathrm{P}<0.001\right)$, and altitude and river length $\left(r_{s}=0.555, \mathrm{P}<0.01\right)$. Based on the Wald $\chi^{2}$ values of the full model we retained slope, altitude, river length and distance from forest edges in the logistic model. The stepwise selection procedure indicated that an increase in one unit $(50 \mathrm{~m})$ of altitude decreased the probability of tigers occurring $(\mathrm{P}<0.019$, odds ratio $=0.004$, $95 \% \mathrm{CI}=0.001-0.403)$. Inversely, an increase in one unit $(50 \mathrm{~m})$ of distance from forest edges increased the probability 
of tigers occurring $(\mathrm{P}<0.043$, odds ratio $=5.646,95 \%$ $\mathrm{CI}=1.059-30.093)$. The Pearson $(\mathrm{P}>0.194)$ and deviance $(\mathrm{P}>0.6677)$ goodness-of-fit tests indicated a good fit because the observed values did not significantly differ from the values expected under the model in question.

The predictive model of tiger distribution was developed based on altitude and distance from forest boundaries, the two environmental variables included as the best predictors of tiger presence in the stepwise selection procedure. Based on the model we predicted $24.8 \%$ of the total landscape to be poor, $57.6 \%$ medium and $17.6 \%$ high quality habitat. Most of the high quality habitat was at the periphery of the Park (Fig. 1).

\section{Discussion}

This study is both the first to estimate tiger population size and density in Batang Gadis National Park. The results provide an estimate of the tiger population in the Park for the global tiger conservation assessment (Sanderson et al., 2006). The estimated range of population sizes from this study, together with the current development of infrastructure and conservation intervention in the Park, could potentially promote the Park's current status as Tiger Conservation Landscape level 3 and long-term priority (Sanderson et al., 2006) to Tiger Conservation Landscape level 2 and regional priority.

The Mh model estimated a mean of six tigers in the sampled area. The high CV of the model may be a result of low sample size and unequal sampling efforts between replicates. The mean density of 1.8 tigers per $100 \mathrm{~km}^{2}$ is comparable with other studies in high elevation tiger habitats in Sumatra. Linkie et al. (2003) found a relationship between altitude and relative abundance in Kerinci Seblat National Park in Central Sumatra, and estimated tiger densities of 2.0 and 1.5 per $100 \mathrm{~km}^{2}$ in hill and submontane forests, respectively (Linkie et al., 2006). Similarly, a tiger density of 1.7 per $100 \mathrm{~km}^{2}$ was estimated in the Bukit Barisan Selatan National Park in Southern Sumatra (O'Brien et al. 2003). Other studies in mainland Asia have also shown a wide variance in estimated tiger densities, with a range of 1.1-6.2 tigers per $100 \mathrm{~km}^{2}$ in Peninsular Malaysia (Kawanishi \& Sunquist, 2004), $2.4-8.7$ per $100 \mathrm{~km}^{2}$ in Thailand (Simcharoen et al., 2007) and 1.98-7.31 per $100 \mathrm{~km}^{2}$ in Badhra, India (Karanth \& Nichols, 2000).

Tigers are considered to be habitat generalists (Schaller, 1967). However, this study found that the abundance of Sumatran tigers decreased with increasing altitude, as is the case in Bukit Barisan Selatan National Park (Wibisono, 2006) and Kerinci Seblat National Park (Linkie et al., 2006). Higher elevations usually have more rugged terrain and thus a poorer prey base. Our predictive model did, however, indicate that good quality tiger habitat tended to be high in forest-town peripheries at some locations, in con- trast to a recent study in selectively logged primary forest around Kerinci Seblat National Park (Linkie et al., 2008). Thus, our model could serve as a preliminary indicator of where conservation intervention should be concentrated with regard to tiger-human conflict mitigation and habitat protection.

Batang Gadis is a new National Park connecting two larger forest blocks of the Angkola and Barumun-Rokan ecosystems (Fig. 1). We detected the same tiger individual at two different camera locations at the northern and southern sections of the Park. It was unlikely that the tiger travelled through the villages dissecting the two sections. Rather, it probably moved through the connecting narrow isthmus of forest (Fig. 1). The Park therefore potentially serves as an important corridor for the Angkola and BarumunRokan ecosystems. The presence of tigers in such ecosystems has been confirmed by North Sumatra's Biodiversity Conservation Agency. Combining the Batang Gadis National Park with the Angkola and Barumun-Rokan ecosystems may increase the area's Tiger Conservation Landscape status from level 3 to level 1 (Sanderson et al., 2006). We estimate that Angkola, Batang Gadis National Park and Barumun-Rokan have a combined total area of c. $6,500 \mathrm{~km}^{2}$. Applying the estimated Batang Gadis National Park tiger density to this entire landscape gives an estimated tiger population of 117 , representing a substantial contribution to the global Sumatran tiger population. Therefore, we believe that Batang Gadis National Park, together with the Angkola and BarumunRokan ecosystems could serve as a stronghold for tiger populations in northern Sumatra. The next step would be to develop an appropriate tiger management plan for this landscape, identify the conservation activities required, and outline the roles and responsibilities of the different agencies involved. The entire Batang Gadis, Angkola and BarumunRokan ecosystem should then be reevaluated and possibly upgraded to a higher level Tiger Conservation Landscape.

\section{Acknowledgements}

This study was part of a collaborative effort between Conservation International Indonesia and the Indonesian Ministry of Forestry's Department for Forest Protection and Nature Conservation, and was technically assisted by the Wildlife Conservation Society Indonesia Program. The work was funded by the US National Fish and Wildlife Foundation, Save the Tiger Fund, the Exxon Mobil Corporation, and Global Conservation Fund. We would like to thank Dr Jatna Supriatna, Dr Susie Ellis, Dr Noviar Andayani, Iwan Widjayanto, Dr Nick Brickle, Dr Mahendra Shrestha, Dr Didy Wurjanto, Maggie Meyer, Nenita de Guzman, Dr Jim Sanderson, Dr Erwin Widodo, Effendy Sumardja, Purbasari Surjadi, Kusuma Paramitha, Dian Melur, Madonna, Agus W. Boyce, Tengku Afriyenni, all CI staff, and Frida Mindasari Saanin from the Wildlife 
Conservation Society Indonesia Program. Dr Joel T. Heinen provided helpful advice and encouragement. We also thank Batang Gadis National Park staff and the many individuals living around the Park who have supported the project and Sumatran tiger conservation.

\section{References}

BMG (2008) The Indonesia Meteorology, Climatology, and Geophysics Agency: Daily Precipitation Records 2002-2006. Sampali Climatology Station, Medan, South Sumatra, Indonesia.

Borner, M. (1978) Status and conservation of the Sumatran tiger. Carnivore, 1, 97-102.

Dinerstein, E., Loucks, C., Heydlauff, A., Wikramanayake, E., Bryja, G., Forrest, J. et al. (2006) Setting Priorities for the Conservation and Recovery of Wild Tigers: 2005-2015. A User's Guide. WWF, Wildlife Conservation Society, Smithsonian and National Fish and Wildlife Foundation-Save the Tiger Fund, Washington, DC and New York, USA.

Gibвons, J.D. (1978) Nonparametric Methods for Quantitative Analysis. Holt, Rinehart and Winston, New York, USA.

Karanth, K.U., Kumar, N.S. \& Nichols, J.D. (2002) Field surveys: estimating absolute densities of tigers using capturerecapture sampling. In Monitoring Tigers and their Prey: A Manual for Researchers, Managers, and Conservationists in Tropical Asia (K.U. Karanth \& J.D. Nichols), pp. 111-120. Center for Wildlife Studies, Bangalore, India.

Karanth, K.U. \& Nichols, J.D. (2000) Ecological Status and Conservation of Tigers in India. Final Technical Report to the US Fish and Wildlife Service (Division of International Conservation), Washington, DC, USA, Wildlife Conservation Society, New York, USA and Centre for Wildlife Studies, Bangalore, India.

Karanth, K.U. \& Stith, B.M. (1999) Prey depletion as critical determinant of tiger population viability. In Riding the Tiger: Tiger Conservation in Human-dominated Landscapes (eds J. Seidensticker, S. Christie \& P. Jackson), pp. 100-113. Cambridge University Press, Cambridge, UK.

KAWANISHI, K. \& SUnQuist, M.E. (2004) Conservation status of tigers in a primary rainforest of Peninsular Malaysia. Biological Conservation, 120, 329-344.

Linkie, M., Chapron, G., Martyr, D.J., Holden, J. \& LeaderWilliams, N. (2006) Assessing the viability of tiger subpopulations in a fragmented landscape. Journal of Applied Ecology, 43, 576-586.

Linkie, M., Haidir, I.A., Nugroho, A. \& Dinata, Y. (2008) Conserving tigers Panthera tigris in selectively logged Sumatran forests. Biological Conservation, 141, 2410-2415.

Linkie, M., Martyr, D.J., Holden, J., Yanuar, A., Hartana, A.T., Sugardjito, J. \& Leader-Williams, N. (2003) Habitat destruction and poaching threaten the Sumatran tiger in Kerinci Seblat National Park, Sumatra. Oryx, 37, 41-48.

Lynam, A.J., Rabinowitz, A., Myint, T., Maung, M., Latt, K.T. \& Po, S.T.T. (2008) Estimating abundance with sparse data: tigers in northern Myanmar. Population Ecology, 51, 115-121.

Nichols, J.D. \& Karanth, K.U. (2002) Statistical concepts: estimating absolute densities of tigers using capture-recapture sampling. In Monitoring Tigers and their Prey: A Manual for Researchers, Managers, and Conservationists in Tropical Asia (K.U. Karanth \& J.D. Nichols), pp. 121-136. Center for Wildlife Studies, Bangalore, India.

O’Brien, T.G., Kinnaird, M.F. \& Wibisono, H.T. (2003) Crouching tiger, hidden prey: Sumatran tiger and prey populations in a tropical forest landscape. Animal Conservation, 6, 131-139.

Otis, D.L., Burnham, K.P., White, G.C. \& Anderson, D.R. (1978) Statistical inference from capture data on closed animal populations. Wildife Monographs, 62, 1-135.

Rexstad, E. \& Burnham, K.P. (1991) User's Guide for Interactive Program CAPTURE. Colorado State University, Fort Collins, USA.

Sanderson, E., Forrest, J., Loucks, C., Ginsberg, J., Dinerstein, E., Seidensticker, J. et al. (2006) Setting Priorities for the Conservation and Recovery of Wild Tigers: 2005-2015: The Technical Assessment. Wildlife Conservation Society, WWF, Smithsonian and National Fish and Wildlife Foundation-Save the Tiger Fund, New York and Washington, DC, USA.

Santiapillai, C. \& Ramono, W.S. (1987) Tiger numbers and habitat evaluation in Indonesia. Tigers of the World: The Biology, Biopolitics, Management, and Conservation of an Endangered Species (ed. R.L. Tilson), pp. 85-91. Noyes Publications, Park Ridge, USA.

Schaller, G.B. (1967) The Deer and the Tiger: A Study of Wildlife in India. The University of Chicago Press, Chicago, USA.

SEIDENSTICKER, J. (1986) Large carnivores and the consequences of habitat insularization: ecology and conservation of tigers in Indonesia and Bangladesh. In Cats of the World: Biology, Conservation, and Management (eds S.D. Miller \& D.D. Everett), pp. 1-41. National Wildlife Federation, Washington, DC, USA.

Seidensticker, J., Christie, S. \& Jackson, P. (1999) Introducing the tiger. In Riding the Tiger: Tiger Conservation in Humandominated Landscapes (eds J. Seidensticker, S. Christie \& P. Jackson), pp. 1-3. Cambridge University Press, Cambridge, UK. Simcharoen, S., Pattanavibool, A., Karanth, K.U., Nichols, J.D. \& KUMAR, N.S. (2007) How many tigers Panthera tigris are there in Huai Kha Khaeng Wildlife Sanctuary, Thailand? An estimate using photographic capture-recapture sampling. Oryx, 41, 447-453.

Tilson, R.L., Soemarna, K., Ramono, W.S., Lusli, S., TraylorHolzer, K. \& Seal, U.S. (1994) Sumatran Tiger Populations and Habitat Viability Analysis Report. Indonesian Directorate General of Forest Protection and Nature Conservation, Bogor, Indonesia, and IUCN/SSC Conservation Breeding Specialist Group, Apple Valley, USA.

USGS (United States Geological Survey) (2004) ftp://edcftp.cr. usgs.gov/pub/data/srtm/Eurasia/ [accessed 21 March 2004]

Wibisono, H.T. (2006) Population ecology of Sumatran tigers (Panthera tigris sumatrae) and their prey in Bukit Barisan Selatan National Park, Sumatra, Indonesia. MSc thesis, University of Massachusetts, Amherst, USA.

\section{Biographical sketches}

HARIYO T. Wibisono has worked as a field scientist and conservation manager since 1993. His research interest is in the population ecology of large mammals, especially Sumatran tigers. JoE J. FIGEL is currently working on jaguars in Latin America. Sugesti M. ARIF has worked as a field technician since 1998. In this study he was responsible for the day-to-day monitoring of the camera traps. AnTon ARio has worked as a conservation manager since 1998 and specializes in conservation education. АвU H. Luв Is has also worked as a conservation manager since 1998 and specializes in primate ecology. 